Research, part of a Special Feature on Do we need new management paradigms to achieve sustainability in tropical forests?

\title{
Biodiversity Conservation in Southeast Asian Timber Concessions: a Critical Evaluation of Policy Mechanisms and Guidelines
}

\author{
$\underline{\text { Rona A. Dennis }}^{1}$, Erik Meijaard $^{2,3}$ Robert Nasi $^{1,4}$, and Lena Gustafsson $^{5}$
}

\begin{abstract}
Tropical deforestation is leading to a loss of economically productive timber concessions, as well as areas with important environmental or socio-cultural values. To counteract this threat in Southeast Asia, sustainable forest management (SFM) practices are becoming increasingly important. We assess the tools and guidelines that have been developed to promote SFM and the progress that has been made in Southeast Asia toward better logging practices. We specifically focus on practices relevant to biodiversity issues. Various regional or national mechanisms now inform governments and the timber industry about methods to reduce the impact of production forestry on wildlife and the forest environment. However, so many guidelines have been produced that it has become difficult to judge which ones are most relevant. In addition, most guidelines are phrased in general terms and lack specific recommendations targeted to local conditions. These might be reasons for the generally slow adoption of SFM practices in the region, with only a few countries having incorporated the guidelines into national legislation. Malaysia, Indonesia, and Laos are among the frontrunners in this process. Overall there is progress, especially in the application of certification programs, the planning and management of high conservation value forests, the regulation and control of hunting, and silvicultural management. To reduce further forest loss, there is a need to accelerate the implementation of good forest management practices. We recommend specific roles for governments, the forestry industry, and nongovernmental organizations in further promoting the implementation of SFM practices for biodiversity conservation.
\end{abstract}

Key Words: biodiversity conservation; certification; logging, Southeast Asia; sustainable forest management; timber production

\section{INTRODUCTION}

The forests of Southeast Asia are species rich and provide important ecological and economic functions (Food and Agriculture Organization 2005). However, they also exhibit high rates of deforestation and degradation (Table 1). This is the main reason why the need for sustainable forest management (SFM) is recognized throughout the region. Since the late 1980 s, there has been a marked increase in the number of instruments available to achieve SFM. The main impetus was provided by the Rio Earth Summit in 1992, which highlighted many problems in the forestry sector, particularly in the tropics, where a lack of sustainable forest management was leading to rapid deforestation. New tools and instruments that have been developed and promoted since then include: criteria and indicators for sustainable forest management, certification standards for forest management, reduced-impact logging techniques, codes of practice for forest management and forest harvesting, and the creation of model forests.

In Southeast Asia, the implementation of SFM tools is increasing at both the government level, as part of forestry legislation, and the level of forest management units. Most forests in Southeast Asia are public or state lands and are allocated for production through concessions (Table 2). This determines the main foci of various SFM tools that are developed. For example, national guidelines and codes of practice define general management standards for each country. Criteria and indicators 
Table 1. Change in forest cover in Southeast Asia. Source: Food and Agriculture Organization (2006).

\begin{tabular}{|c|c|c|c|c|c|c|}
\hline & \multirow[b]{2}{*}{$\begin{array}{l}\text { Forest area in } 1990 \\
(\times 1000 \mathrm{ha})\end{array}$} & \multirow[b]{2}{*}{$\begin{array}{l}\text { Forest area in } 2000 \\
\quad(\times 1000 \mathrm{ha})\end{array}$} & \multirow[b]{2}{*}{$\begin{array}{l}\text { Forest area in } 2005 \\
\quad(\times 1000 \mathrm{ha})\end{array}$} & \multicolumn{2}{|c|}{ Annual rate of change $(\%)$} & \multirow[b]{2}{*}{$\begin{array}{l}\text { Proportion of } \\
\text { land area } \\
(\%)\end{array}$} \\
\hline & & & & 1990-2000 & $2000-2005$ & \\
\hline Brunei & 313 & 288 & 278 & -0.80 & -0.70 & 52.8 \\
\hline Cambodia & 12,986 & 11,541 & 10,447 & -1.10 & -2.00 & 59.2 \\
\hline Indonesia & 116,567 & 97,852 & 88,495 & -1.70 & -2.00 & 48.8 \\
\hline Laos & 17,314 & 16,532 & 16,142 & -0.50 & -0.50 & 69.9 \\
\hline Malaysia & 22,376 & 21,591 & 20,890 & -0.40 & -0.70 & 63.6 \\
\hline Myanmar & 39,219 & 34,554 & 32,222 & -1.30 & -1.40 & 49.0 \\
\hline Philippines & 10,574 & 7949 & 7162 & -2.80 & -2.10 & 24.0 \\
\hline Thailand & 15,965 & 14,814 & 14,520 & -0.70 & -0.40 & 28.4 \\
\hline East Timor & 966 & 854 & 798 & -1.20 & -1.30 & 53.7 \\
\hline Vietnam & 9363 & 11,725 & 12,931 & 2.30 & 2.00 & 39.7 \\
\hline
\end{tabular}

are developed as general industry standards, whereas certification is aimed primarily at privately owned companies that lease concession rights from governments and that are influenced by growing consumer demand for better forest management. Most of the tools and guidelines focus on the silvicultural and operational aspects of forest management such as concession planning, directional felling, road design, and waste management. Other tools such as the Forest Stewardship Council certification criteria also address socio-cultural issues and high conservation value. Few tools adequately address biological issues, and those in existence provide little detail on the steps required to retain species diversity in production forestry areas (Meijaard et al. 2005).

There is an increasing body of literature that has assessed the effects of selective timber extraction and associated processes (hereafter referred to as logging) on the population density of forest wildlife (for an overview see Fimbel et al. 2001, Meijaard and Sheil 2007b). Selective logging, which is the prevailing logging system in Southeast Asia, means the removal of certain trees in a stand as defined by specific criteria. Here, we do not address clearcut felling, which is the total removal of trees. Logging affects the ecological processes in timber concessions by removing biomass, changing forest structural characteristics, changing light regimes, and altering microclimatic conditions at both the ground and canopy levels. Logging also introduces people into the forest, increases access via logging roads, and generally increases disturbance. The unsurprising result is that forest species are affected; how they are affected depends on the species' ecology and the intensity of the forest disturbance, with some species benefiting even from highdisturbance logging and others being negatively affected by the slightest disturbance (Meijaard et al. 2005). Overall, it appears that selective logging conducted according to SFM guidelines has a 
Table 2. Ownership of production forests in Southeast Asia. Source: Food and Agriculture Organization (2006).

\begin{tabular}{lccc}
\hline \hline Country & $\begin{array}{c}\text { Forest area in } 2000(\times \\
1000 \text { ha })\end{array}$ & $\begin{array}{c}\text { Public ownership } \\
(\%)\end{array}$ & $\begin{array}{c}\text { Private ownership (\%) } \\
(\%)\end{array}$ \\
\hline Brunei & 288 & 100 & Other ownership \\
Cambodia & 11,541 & 100 & \\
Indonesia & 97,852 & 100 & \\
Laos & 16,532 & 100 & 7 \\
Malaysia & 21,591 & 93 & 10 \\
Myanmar & 34,554 & 100 & 13 \\
Philippines & 7949 & 90 & 67 \\
Thailand & 14,814 & 87 & 18 \\
East Timor & 854 & 33 & \\
Vietnam & 11,725 & 56 & \\
& & & \\
\hline
\end{tabular}

moderate impact on forest wildlife, and no species have gone extinct because of logging alone. Concessions in which such logging is implemented can play an important role in the conservation of forest wildlife (Meijaard 2007, Meijaard and Sheil $2007 a, b)$.

In the knowledge that good logging has a relatively limited impact on forest biodiversity, we wanted to know what progress has been made in Southeast Asia toward better logging. Our specific objective was to assess which SFM practices have been developed, with a specific focus on those practices relevant to biodiversity issues. Such an overview identifies not only what has been achieved, but more importantly, the remaining gaps. This helps to focus specific programs, for instance, the development of national guidelines, training for concession managers, or support from academic institutions or nongovernmental organizations, in those countries in which such programs are most needed. Another objective was to determine whether the adoption of SFM practices is starting to change the industry at large or whether there are only sporadic improvements from a handful of enlightened concession owners.

\section{METHODS}

We focused our review on all countries in Southeast Asia, including those without an active timber industry: Brunei, Cambodia, East Timor, Indonesia, Laos, Malaysia, Myanmar, the Philippines, Singapore, Thailand, and Vietnam (Fig. 1). For each of these countries, we sought reports and scientific publications, as well as information from Internet websites. A complete overview of the literature is provided in Gustafsson et al. (2007). Our search involved formal bibliographical searches, as well as consultations with local, national, and international experts, to identify all potentially relevant documents, as well as unpublished information. Through the synthesis and critical assessment of the literature and other knowledge, we assessed the extent to which biodiversity guidelines have been 
developed, the level of detail that they provide, and the extent to which they have been implemented on a country-by-country basis.

\section{RESULTS}

\section{Brief overview}

Many of the countries considered in this review do not yet have official or even draft guidelines for biodiversity considerations in logging concessions. Only Cambodia, Indonesia, Laos, Malaysia, and Vietnam have initiatives related to biodiversity in logging concessions. These range from actual guidelines in Cambodia and Malaysia to Forest Stewardship Council (FSC) certification of production forests in Indonesia and Laos. Six of the eleven countries examined are members of the International Tropical Timber Organization (ITTO): Cambodia, Indonesia, Malaysia, Myanmar, the Philippines, and Thailand. The members support the development of sustainable forest management practices. All but two of the countries, i.e., Brunei and Singapore, are members of the Asia-Pacific Forestry Commission, one of six Food and Agriculture Organization Regional Forestry Commissions that cover the world's major geographic regions. All countries except Brunei are party to the Convention on Biological Diversity; however, Cambodia, East Timor, and Laos are party to the treaty through accession, having not signed the treaty itself.

\section{Codes of practice}

The first tool we assessed was the codes of practice (CoP), which had its beginnings in the work carried out in the South Pacific in the early 1990s (Durst et al. 2003). The CoP is intended to encourage improved forest management while reducing detrimental environmental and social impacts. The principal effort in the region has centered on the development and implementation of the regional Code of Practice for Forest Harvesting in AsiaPacific (Food and Agriculture Organization 1999). The Asia-Pacific Forestry Commission has taken a leadership role in supporting the formulation of $\mathrm{CoP}$ for forest harvesting in the region. Political support for the process was enhanced by formal Association of Southeast Asian Nations endorsement of the regional $\mathrm{CoP}$ in 2001. A recent review, however, found that the development and implementation of the CoP have not yet been universally successful across the region (Asia-Pacific Forestry Commission 2006). To date, only five countries have produced national CoP: Cambodia, Indonesia, Laos, Malaysia, and Myanmar (Table 3). In some countries, political instability, weak law enforcement, illegal logging and trade, and the increased demand for timber by wood industries have hampered the development and implementation of national $\mathrm{CoP}$ (Asia-Pacific Forestry Commission 2006).

To understand what the CoP intend to achieve for biodiversity conservation, we examined in more depth the Indonesian CoP (Ministry of Forestry and Estate Crops 2000). In these CoP, various references are made to aspects of ecology and biodiversity. They focus on setting aside reserve areas within production units and the protection of species and ecosystems with high conservation value. A quick review of these prescriptions suggests that although well intended, the lack of specific practical guidelines leaves much room for interpretation. For example, how much forest should be set aside for viable populations of plants and animals? How many habitat trees should be retained? In addition, the $\mathrm{CoP}$ pay little or no attention to important secondary effects like hunting, river siltation, or soil compaction. As Meijaard et al. (2006) showed, the secondary effects can affect wildlife as much, if not more, than the primary effects of logging.

At present, all CoP are voluntary, with operators encouraged, but not required, to adopt the recommended techniques and procedures. If compliance with the national codes were made a legal requirement, it would enforce their adoption and consequently improve timber harvesting. Despite their shortcomings, CoP in Southeast Asia do provide a basis for governments to define specific forestry regulations regarding biodiversity conservation actions in concessions.

\section{Criteria and indicators}

One of the key global strategies for the promotion of sustainable forest management (SFM) is through the development and implementation of criteria and indicators (C\&I) as a means to benchmark and measure progress toward specific objectives. The ITTO pioneered the development of C\&I; its member countries endorsed the ITTO criteria for sustainable tropical forest management in 1992 (International Tropical Timber Organization 1993). 
Fig. 1. Land cover map for Southeast Asia in 2000. Source: Stibig et al. (2003).

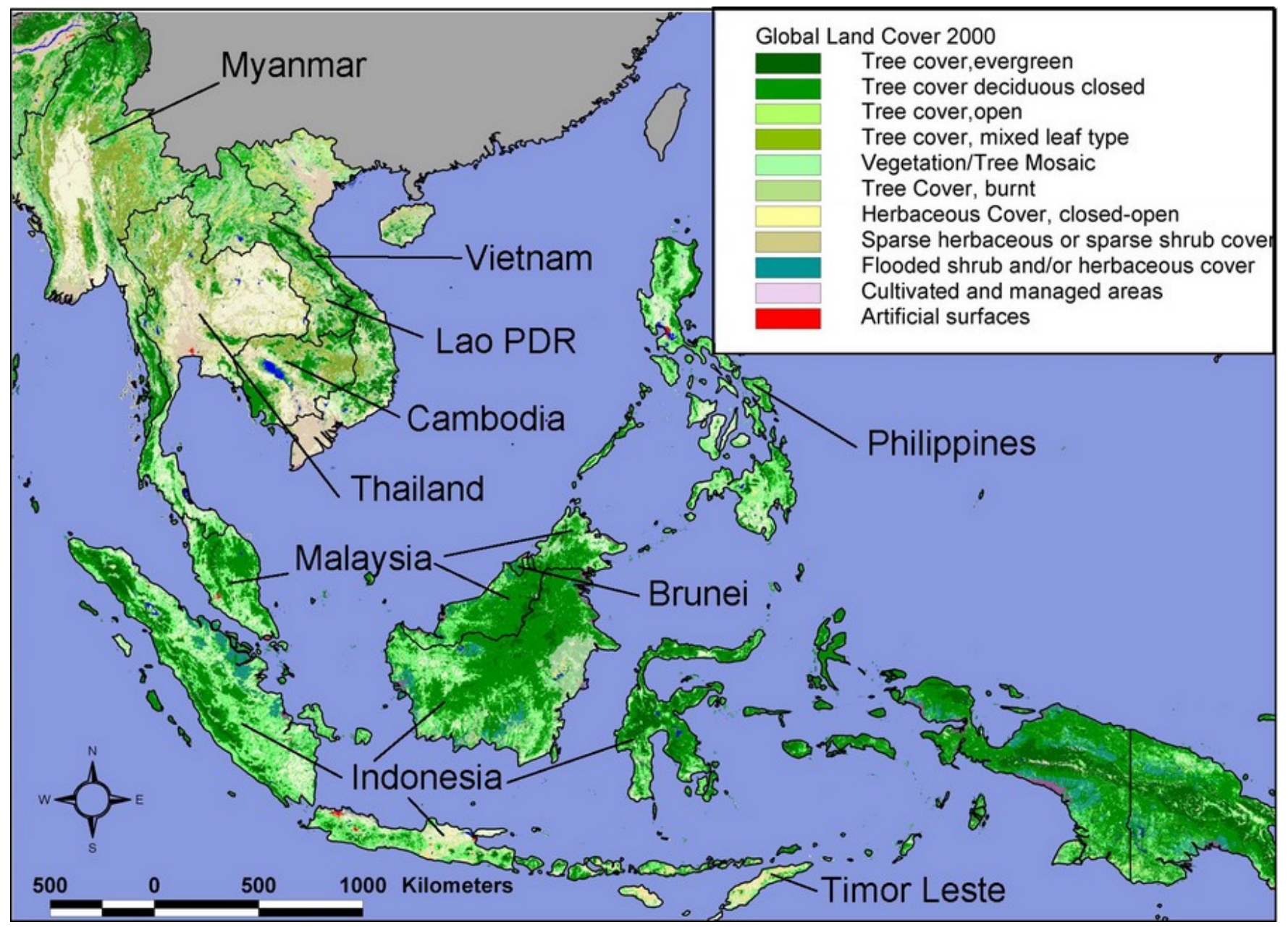

Within the Asia-Pacific region, the C\&I process is well established in only two countries: Indonesia and Malaysia. The ITTO C\&I principles and indicators were also used as the basis for the Malaysian and Indonesian forest certification schemes (see Results: Certification) and in the initial development of the FSC principles and criteria (Bennett 2004).

In 2006, the World Conservation Union (IUCN) produced draft guidelines intended to update and replace the 1993 ITTO Guidelines for the Conservation of Biological Diversity in Tropical Production Forests (International Tropical Timber Organization 1993, World Conservation Union
2006). The 2006 IUCN draft guidelines focus on measures additional to the ITTO guidelines that favor biodiversity. The IUCN uses "ecosystem approach principles" as adopted by the Convention on Biological Diversity in 2000, which imply that all situations are different and that there are multiple ways of managing forests, all of which can be considered sustainable and all of which have impacts on biodiversity. In developing the guidelines, the IUCN has attempted to distinguish two levels of intervention: general approaches to forest management that will have wide application in ensuring that biodiversity values are maintained and should be universally adopted, and a much broader set of technical suggestions that managers 
Table 3. Status of codes of practice in Southeast Asian timber producing nations as of 2007.

\begin{tabular}{ll}
\hline \hline Country & Codes of practice for timber harvesting \\
\hline Brunei & None found \\
Cambodia & Cambodian Code of Practice for Forest Harvesting, July 1999 \\
Indonesia & Principles and Practices of Timber Harvesting in Indonesia, 2000 \\
Laos & National Code of Timber Harvesting Practices in Lao, 2005 \\
Malaysia & Code of Practice for Harvesting of Natural Inland Forest and Code \\
Myanmar & Harvesting of Mangrove Forest, Peninsular Malaysia, 1997 \\
Philippines & National Code of Timber Harvesting Practices in Myanmar, 2000 \\
Singapore & Codes of practice not yet published \\
Thailand & Not applicable: Singapore has no production forestry \\
East Timor & None found \\
Vietnam & Currently developing forest policy \\
& Currently drafting codes of practice
\end{tabular}

and decision makers might draw upon in designing locally applicable guidelines, CoP, regulations, and silvicultural practices.

The IUCN principles, guidelines, and recommended actions assign the main responsibility for each of their recommended actions to: foresty and environmental government agencies; specialized biodiversity organizations, international nongovernmental organizations, and research institutes; local nongovernmental organizations, civil society, and community organizations; forest managers and concessionaires; and educational and technical training institutions. This is helpful because it allows the development of clear plans with responsibility assigned to those institutions that are most capable or likely to address the recommended actions. The latest draft of the guidelines was released in September 2007.

\section{Reduced-impact logging}

Moving to specific operational guidelines, reducedimpact logging (RIL) consists of technologies and practices that are designed to minimize environmental impacts from timber harvesting operations (Sist et al. 1998, Klassen 2006). RIL is part of a shift in forestry methods worldwide toward promoting SFM. To standardize the definition, application, and verification of RIL, the Tropical Forest Foundation has developed a detailed set of tools applicable to the Southeast Asia situation (Klassen 2006).

Biodiversity considerations do not yet figure much in RIL recommendations, which focus more on minimizing damage to residual stock, regeneration, soil properties, and water courses. RIL recommendations that explicitly mention the environment include: preharvest planning of roads, skid trails, and landings; the development of written environmental and operational standards to guide planning and operational activities; and the 
integration of these standards into the company structure (Klassen 2006). RIL guidelines also recommend the marking, recording, and mapping of protected tree species and the identification and mapping of ecologically sensitive sites such as special wetland habitats, cave habitats, and nesting trees during the inventory (Klassen 2006).

The debate about the adequacy of RIL as a tool to minimize damage to residual stands is a good example of the need to consider forest ecology issues before making generic recommendations (Fredericksen and Putz 2003, Sist and Brown 2004); RIL is a tool to minimize damage to the residual stand. It does not, however, ensure sustainability because it does not address the issue of regeneration of desired species. Sustainability requires the regeneration of desired species, which depends largely on the interaction between the ecology, dynamics, and harvesting regime of the forest type under consideration.

\section{Certification}

Forest certification emerged in the early 1990s as an instrument for promoting SFM. The most widely accepted of all international certification schemes is that developed by the FSC in 1993 (Nussbaum and Simula 2004). As of November 2007, within Southeast Asia, three countries have FSC-certified natural forests, and Thailand and Vietnam have two and one certified plantations, respectively (Table 4).

Two countries in the region have developed their own national certification schemes. In 1992 , Indonesia established the Indonesian Ecolabeling Institute (Lembaga Ekolabel Indonesia, LEI). This was followed in 1998 by the Malaysian Timber Council scheme. In Myanmar, the Timber Certification Committee is apparently a national certification scheme.

The LEI is an independent foundation that was developed by a working group of nongovernmental organizations and academics. The LEI developed its own set of C\&I based on the ITTO guidelines for SFM. In Indonesia, companies have a choice between either FSC or LEI certification. The LEI, however, does not yet have international recognition, which means that it has less prestige than the FSC in the international marketplace. The systems are different, for example, in relation to the plantation forestry sector: companies that have plantations established on land that was still forested after 1994 do not qualify for FSC certification, but are eligible for LEI certification.

The Malaysian Timber Certification Council (MTCC) was created in October 1998 as a joint initiative by the Malaysian Ministry of Primary Industries and the Malaysian Timber Industry Development Council (now Malaysian Timber Council). It is an independent organization that was established to develop and operate a voluntary national timber certification scheme in Malaysia to provide assessments of forest management practices and to meet the demand for certified timber products. The MTCC timber certification scheme began operation in October 2001. The standard currently used to assess forest management units for the purpose of certification is the Malaysian Criteria and Indicators for Forest Management Certification [MC\&I(2002)] (Malaysian Timber Certification Council 2004), which is a result of collaboration between the MTCC and FSC.

\section{High conservation value forests}

The concept of high conservation value (HCV) was added to the FSC forest management principles in the late 1990s as Principle 9 (Jennings 2004). HCV includes environmental and social values that are considered to be of outstanding significance or critical importance. Examples may include concentrations of endangered species, a stream that is the sole source of water to a local community, or a site with special religious significance. Of the six $\mathrm{HCV}$ categories under the FSC principles, three deal specifically with biodiversity: HCV 1, concentrations of biodiversity; $\mathrm{HCV}$ 2, large landscape-level forests; and HCV 3, rare or endangered ecosystems.

The FSC provided the first definitions of HCV. The definitions were subsequently streamlined and elaborated by the independent company ProForest, which developed the HCV forest (HCVF) assessment guidelines in the HCVF Global Toolkit between 2001 and 2003; this toolkit has been in use since 2001 (Jennings et al. 2003, Judd et al. 2003a, $b, c)$. National interpretations of the HCVF toolkit have also been developed: an Indonesia toolkit (ProForest/Rainforest Alliance 2003); a Vietnam toolkit, which is currently being drafted; and Laos draft guidelines on $\mathrm{HCV} / \mathrm{HCVF}$ assessment (Sustainable Forestry and Rural Development Project 2006). 
Table 4. Overview of natural and plantation forests in Southeast Asia certified by the Forest Stewardship Council.

\begin{tabular}{lcccc}
\hline \hline Country & $\begin{array}{c}\text { Natural forest } \\
\text { (ha) }\end{array}$ & $\begin{array}{c}\text { Natural forest } \\
\text { (no.) }\end{array}$ & $\begin{array}{c}\text { Plantation forest } \\
\text { (ha) }\end{array}$ & $\begin{array}{c}\text { Plantation forest } \\
\text { (no.) }\end{array}$ \\
\hline Indonesia & 702.610 & 4 & $\sim 6500$ & 2 \\
Laos & 44.985 & 2 & & 3 \\
Malaysia & 55.083 & 1 & 42,500 & 2 \\
Thailand & & & 4.749 & 1 \\
Vietnam & & & 9.904 & 8
\end{tabular}

Note: As of January 2008, from various sources.

Increasingly, companies and nongovernmental organizations are using the HCVF concept and the toolkits outside of the FSC framework. In total, approximately $6.15 \times 10^{5}$ ha have been identified and proposed as HCVF set-asides in Southeast Asia at the forest management unit level, or approximately $0.3 \%$ of all remaining forests in Southeast Asia (Appendix 1). Further HCVF assessments are being planned. A recent overview by the Nature Conservancy Asia-Pacific identified 37 timber concessions in Southeast Asia as likely candidates for improved forest management and $\mathrm{HCVF}$ assessment (Cole Cenge personal communication). The total area of these concessions is $2.1 \times 10^{6}$ ha, of which $1.454 \times 10^{6}$ ha is in Indonesia, $5.46 \times 10^{5}$ ha is in Malaysia, $7.0 \times 10^{4}$ ha is in Vietnam, $2.0 \times 10^{4}$ ha is in Cambodia, and $1.0 \times 10^{4}$ ha is in Laos.

In addition to these forest management unit level assessments, the World Wide Fund for Nature (World Wildlife Fund) Indonesia Program has also performed landscape-scale HCVF assessments, including for all of West Kalimantan province and for two regencies in Papua province. Similar landscape-level assessments are now being planned for several districts in West Kalimantan and Central Kalimantan provinces. Malaysia has also conducted various HCVF assessments at the landscape level, either for FSC or $M C \& I(2002)$ certification. This rapid development of new aspects of HCVF use requires careful assessment of new standards and protocols that may diverge from the original FSC concept. This is especially relevant because forest and plantation industries are increasingly becoming involved in the development of HCVF assessment tools; because many plantations are established on nonforest land, the interpretation of HCVF is likely to differ from that in selectively harvested timber concessions.

\section{Specific biodiversity guidelines}

Specific biodiversity guidelines for timber production areas were only found for four of the eleven countries examined: Cambodia, Indonesia, Laos, and Malaysia (Sarawak), with only the Malaysian state of Sarawak officially adopting these guidelines as policy.

\section{Cambodia}

Of all of the countries examined, Cambodia has the most comprehensive set of biodiversity guidelines for timber concessions. The Biodiversity 
Conservation Guidelines (BCG) were developed by a World Bank forest concession management project (Directorate of Forestry and Wildlife 2002). The Wildlife Conservation Society (WCS) Cambodia provided detailed input to earlier versions of the guidelines. The guidelines provide a logical conceptual orientation for the concession planner by reviewing the relevance of biodiversity to forestry concessions, the general principles of forest biodiversity management, key characteristics of Cambodian biodiversity, and the legal framework for its protection. The guidelines discuss the different levels of biodiversity management and identify key tasks at each level. Starting at the regional scale, they stress the importance of viewing the forest management unit as part of the wider landscape and its constituent parts. The level of conservation planning guidance within the forest management unit is fairly detailed, especially for aspects such as keystone species. The issue of hunting is particularly well covered, and a complete ban on hunting and close monitoring of the ban is recommended. However, the BCG do not provide detailed guidelines on how ecological surveys and planning that are carried out prior to logging should be achieved. This is a specialized task and requires considerable training and knowledge; partnership with conservation organizations may be one means of achieving this. The WCS did partner with a timber concession in Cambodia until a logging freeze came into effect in 2002.

\section{Indonesia}

Meijaard and colleagues (Meijaard and Sheil 2007a, $b$, Meijaard et al. 2005, 2006) recently reviewed the wildlife literature for Borneo and demonstrated how the application of conservation planning and implementation such as good road building and RIL methods can benefit wildlife. They provided detailed and practical recommendations that could directly benefit wildlife in timber concessions. After consultation with practitioners, these guidelines were further refined and made more specific (Gustafsson et al. 2007).

The main recommendations of Meijaard and colleagues (Meijaard and Sheil 2007a,b, Meijaard et al. 2005, 2006) are to retain contiguous forest as far as possible. Reducing the width of roads and tracks and limiting felling-gap sizes should limit the effects of fragmentation on arboreal species. Meijaard and colleagues recommend the regulation of hunting in timber concessions and suggest how this can be done based on WCS methods. The hunting of vulnerable and protected species should be eliminated. Various types of ecologically important habitat structure (e.g., large trees, hollow trees, and old fruit gardens) and location (e.g., pools, wallows, saltlicks, and riverside habitats) should be identified and maintained when possible. Certain plant species and genera that are important habitat components (some of which are listed by Meijaard et al. 2005) should be retained when possible. Conserving the mid-canopy by minimizing incidental tree damage is a good strategy for conserving a whole host of palms and fruiting trees. Meijaard and colleagues also assessed the impact of understory slashing on wildlife, which is currently a legal requirement in Indonesia, and recommend that it be discontinued.

\section{Laos}

A proposal for official guidelines on how to monitor biodiversity values relevant for managing production forest areas in Laos was prepared in 2006 (Sustainable Forestry and Rural Development Project 2006). These guidelines were precipitated by a review of HCVF assessments that were carried out in two production forest areas by a World Bank/ Finnish forestry project (Sustainable Forestry and Rural Development Project 2006). These guidelines, however, still remain in a draft state and have not yet been adopted by the government. The guidelines recommend that annual biodiversity surveys be carried out in the production forest areas by staff from the Department of Forestry. There are detailed requirements about who should be on the team, the equipment required, and the need for forward budget planning to allocate funds for the activity. The World Bank/Finnish forestry project team has also carried out baseline biodiversity surveys in six production forest areas (Poulsen et al. $2005,2006)$. These surveys were carried out to prepare HCVF assessments.

\section{Sarawak, Malaysia}

In 1997, the Sarawak Government adopted A Master Plan for Wildlife in Sarawak as official government policy. This master plan was co-written by staff from the WCS and the Sarawak Forestry Department. Its two core themes were the control of unsustainable hunting and the conservation of wildlife in various land categories. The implementation of this plan has included legislative changes that incorporated a total legal ban on sales 
of wildlife taken from the wild, regulations to control hunting in logging concessions, and the control of modern hunting technologies. The implementation involved state-wide conservation education and enforcement programs, formal training for government staff, the creation of important new protected areas, and reductions in sales of shotgun cartridges. The results have been an increase in protected areas and declines in the wildlife trade (Bennett 2004).

Since 2001, the WCS has been working with the Sarawak Forestry Department and Samling Corporation (a logging company) on a project designed to implement the Master Plan for Wildlife in Sarawak. In particular, the project addresses legal restrictions on the trade in wildlife, as well as work with local communities to reduce hunting pressure on wildlife in the logging concession. The Samling concession is certified under the MTCC scheme because RIL techniques have been used in the concession. The logging company contributes to the cost of the biodiversity surveys.

\section{Regional sustainable forest management networks}

Finally, we want to draw attention to several SFM programs that are active at a regional level. Although none of these have a specific focus on biodiversity, they are important to promote the implementation of SFM practices in the region. Since the 1950s, a number of regional forest fora have been developed in the Asia-Pacific region, with the goal of catalyzing policy changes that will encourage a more enabling environment for improved forest management. These networks have different objectives, but generally focus on providing a forum to bring together governments or governments and nongovernmental organizations. The private sector has not played a major role in these fora up until now (Appendix 2). Recent developments have sought to change this. In 2007, the United States Agency for International Development awarded the Nature Conservancy a 3$\mathrm{yr}$ cooperative agreement to implement the Responsible Asia Forestry and Trade Program. The Nature Conservancy is leading a consortium of public and private organizations and nongovernmental organizations, including the IUCN, the World Wide Fund for Nature, the Tropical Forest Foundation, the Tropical Forest Trust, the Wildlife Trade Monitoring Network, the Regional Community Forestry Training Centre, the Association of Southeast Asian Nations, the ITTO, ScanCom,
DLH Nordisk, The Home Depot, Lowe's, and Xerox. The goal of the program is to improve both the quality and extent of the sustainable management of forest resources and biodiversity.

\section{DISCUSSION}

\section{Starting to see the wood for the trees}

Our review shows that since the 1990s, there has been considerable progress in the development of tools and guidelines that help forestry practitioners manage wildlife populations in production forests. Many different guidelines exist at global, regional, and national levels. The plethora of information makes it difficult for practitioners to determine which guidelines need to be followed. Impediments to the adoption of biodiversity guidelines include the fact that they are usually not mandatory requirements and only become enforceable when stipulated in an approved license, plan, permit, or contract. Guidelines are designed without rigid prescriptions and allow for flexible decision making through well-planned and monitored adaptive management and research. Decisions should be based on local site conditions, the needs of local users, site-specific biodiversity conservation considerations, and technical innovation. At the same time, guidelines must express clear expectations and should be written in such a way as to reduce the chance of misinterpretation. Even when it comes to codes of practice (CoP) guidelines for established silvicultural and harvesting techniques, which have been available for many years, there is still poor implementation in some countries and in general, there is a lack of revision and updating of techniques and a failure to reflect new research results and lessons learned (AsiaPacific Forestry Commission 2006). There is also a general lack of monitoring and evaluation mechanisms. Overall, despite progress, there is much room for improvement.

Despite the relatively slow pace of the adoption of certification in Southeast Asia, it is widely recognized as a useful tool to stimulate movement toward sustainable forest management (SFM) at the forest management unit level. However, because certification is a site-based tool, its role in influencing the wider landscape beyond the single concession is limited. This is particularly true in areas where logging concessions may be small in size. Therefore, governments should not rely 
heavily on the image of certified forests as the key to SFM and forget that overall appropriate land-use planning is the key to managing forested landscapes sustainably and to maintaining biodiversity.

We emphasize that there are still significant gains to be made for wildlife conservation in Southeast Asian timber concessions. An area of $>2.0 \times 10^{8}$ ha of forest remained in 2005 (Food and Agriculture Organization 2006); on average, $42 \%$ of that area has production forestry as its primary function. This means that the continued improvement of forest management in the remaining forests can still make a significant contribution to the conservation of forest species in the region.

\section{Getting down to details while retaining general applicability}

Many of the various SFM tools are phrased in rather vague terms and leave potential users with questions of how these actions should be implemented. Most guidelines fall short of their goal to provide technical suggestions to managers and decision makers that would allow them to develop locally applicable management regulations. Unfortunately, concession managers and policy developers are unlikely to develop specific regulations unless they are spelled out in detail by someone else. For instance, a (hypothetical) guideline "to minimize barrier functions of roads to animal dispersal" could be significantly strengthened by stipulating that "main roads should have narrow sections every 50 $\mathrm{m}$ where the road width is a maximum of $7.5 \mathrm{~m}$ and tree crowns touch overhead." The development of such detailed guidelines requires collaboration between forest practitioners (e.g., is such a regulation feasible and safe?), researchers (e.g., would such regulation indeed benefit animal dispersal?), and governments (e.g., would the government be willing to translate the recommendation into legislation?).

\section{Implementation of biodiversity-friendly forest management}

Our country studies indicate that increasingly, governments and forest managers realize the relevance of and necessity for biodiversity monitoring and management within production forest areas. Indonesia and Malaysia appear to be leaders in this field. The development and adoption of timber harvesting $\mathrm{CoP}$ is increasing, and companies in some countries are using or evaluating reduced-impact logging techniques. The number of certified natural forests is increasing annually, with almost $8.5 \times 10^{5}$ ha FSC-certified in the region as a whole and $4.0 \times 10^{6}$ ha MTCC-certified in Malaysia. A comprehensive overview of the areas certified under the Indonesian Ecolabeling Institute was not available. These developments contribute to better logging practices, but the next step is to convince governments and companies that biodiversity within forest management units must be considered in a more integrated manner.

\section{Roles of government, industry, and civil society}

Improving wildlife management in Southeast Asian timber concessions requires the increased acceptance of sustainable forest management concepts by three main stakeholders: governments, the timber industry, and nongovernmental organizations. Governments need to recognize the role of production forestry in wildlife conservation. In Southeast Asia, wildlife conservation focuses strongly on the establishment of protected areas where the forests are specifically managed for species conservation. One of the focal areas of the Convention on Biological Diversity's 2010 Biodiversity Targets is to effectively conserve $10 \%$ of each of the world's ecological regions. This will leave large areas of forest without a recognized role for conservation. To ensure the survival of wideranging and protected forest species, a landscapelevel approach to land-use planning is needed that includes forest management units, protected areas, and other land uses. This would create large contiguous forest landscapes that provide environmental services, revenues from forest use and possibly carbon sequestration, and viable ecosystems with high value for biodiversity conservation. The increasing incorporation of wildlife-related guidelines and regulations into forestry legislation should facilitate the design of such forest landscapes. However, because biodiversity conservation and production forestry are firmly entrenched in different government institutions in most of Southeast Asia, a more fundamental shift may be required in government structure and philosophy before biodiversity conservation becomes an integral part of SFM.

The timber industry needs to recognize that taking on a role as wildlife manager in forest concessions 
might not require a major change in operations and might not be as onerous as initially perceived. Adhering to SFM guidelines should address most general wildlife needs, and the management improvement required for forestry certification should further improve the conditions for forest wildlife. Increasingly, consumer markets and financing institutions demand that timber producers address wildlife issues in timber concessions (Aguilar and Vlosky 2007, Kollert and Lagan 2007), and the lure of a positive public image and access to "green" markets is attracting more and more timber producers into good forest management. There are several examples of timber concessions in the region that significantly strengthened their financial health after being certified because they could attract financing from institutions that would normally be out of reach of the Southeast Asian timber industry (Erik Meijaard unpublished data). Thus, the image that goes with good management and long-term planning is paying off.

Nongovernmental organizations in Southeast Asia have traditionally considered the timber industry as one of the main enemies of forest and wildlife conservation (Meijaard 2007). Several decades of poor or nonexistent forest management justify this distrust, and many nongovernmental organizations still consider the timber industry to be incompatible with the rights of forest-based communities. Rampant deforestation and associated environmental catastrophes forced the Philippines and Thailand to enforce logging bans some time ago, Cambodia is currently experiencing a temporary logging freeze, and nongovernmental organizations are again calling for a logging moratorium in Indonesia (Jakarta Post 2007). Strengthening the role of the timber industry in biodiversity conservation will require improvements in collaborations between the timber industry and local communities, as well as the increased engagement of timber concessionaires with nongovernmental organizations. Common ground between the industry and nongovernmental organizations may be found in the recognition that the timber industry provides critical management input in forests that are outside the protected area network. Governments, the timber industry, and nongovernmental organizations need to work together in Southeast Asia to achieve improved forest management and related biodiversity conservation.

\section{CONCLUSION}

Despite several decades of attempts to improve forest management in Southeast Asia, the implementation of sustainable forest management (SFM) in a significant part of the region's production forests still has a long way to go. Continued rapid forest loss from the timber estate indicates that Southeast Asian governments, in general, no longer consider production forestry in natural forests to be of major economic importance. Most of the easily accessible timber has been removed, and many timber concessions are in their second or third logging cycle. More intensive production in fast-growing plantations is now often favored over production forestry in natural forests.

Still, there are several reasons for guarded optimism. There is increasing recognition of the important role played by natural forests in the provision of environmental and social services. The frequency of natural disasters such as landslides and floods has made the people of Southeast Asia poignantly aware of the importance of forests in preventing these disasters. At the same time, market pressures create a demand for sustainably managed timber. Since the Global Climate Change Conference in Bali in December 2007, there has been heightened focus on production forests as potential carbon sinks and the payments for avoided deforestation that would go with them.

The key to the success of SFM in Southeast Asia is continued support for the various positive trends discussed here. Nongovernmental organizations play an important and growing role in increasing the implementation of SFM. Although some nongovernmental organizations remain opposed to any industrial exploitation of forests, many others actively support the timber industry and are helping to improve management. Nongovernmental organizations, together with research organizations, should continue to provide technical input toward making codes of practice more specific and developing improved tools to monitor the implementation of SFM, as well as to implement objective monitoring programs themselves. They also keep pressure on governments to formalize codes of practice and other guidelines in a national legal framework. In addition, nongovernmental organizations play an important role in further increasing the demand for sustainably managed timber products, either by directly influencing 
markets or by lobbying government to regulate the import of unsustainably produced timber products.

The timber industry itself is starting to recognize the benefits of improved management, both in terms of gaining premium prices for sustainably managed timber, as well as in reducing operating costs in their concessions and in accessing a broader range of financing opportunities. These positive trends are starting to change the way that governments think about the long-term future of production forestry in Southeast Asia. There is a need, however, to consolidate policy and field practice gains to move toward a tipping point at which SFM becomes the private sector norm. Various steps need to be taken in the near future. The number of concessions that are now practicing SFM needs to be extended rapidly to achieve a critical mass of enterprises with significant learning and leverage potential. This requires substantial working capital to address technical management issues in the many timber concessions in the region, and funds need to be raised from both private and public sources. It also requires capacity building within the government, nongovernmental organization, and industry sectors, specifically in participatory planning and conflict management, reduced-impact logging, and high conservation value forest identification and management.

Finally, there is a need for further research. We recognize that forest loss will only be reduced if the Southeast Asian nations and other key stakeholders who influence forest land-use decisions receive more tangible benefits from SFM than they do from unsustainable forest exploitation and conversion. This will only happen if those who exploit forest resources pay the full price for their exploitation and conversion, including the full cost of environmental and social externalities associated with their activities on the ground. A much better understanding of forest economics is needed that takes into consideration all of the direct and indirect values that forests represent. Such knowledge would help in the development of a clearer picture of the real cost of forest exploitation and would substantiate scientifically that SFM is an economically attractive strategy in the region in the long term.

Despite continued deforestation in the region, we suspect that over the next 10 years, the rate of forest loss will be reduced. Much of the easily accessible lowland timber has now been harvested, and many of these ex-forestry concessions have now been converted to timber plantation, oil palm, and other agricultural and silvicultural uses. In the less accessible areas such as hill and mountain forests and, to a certain extent, peat swamps, there is increasing recognition of the economic value of the sustainable use and conservation of tropical forests. We expect to see the stabilization of land use with an increasingly clearly defined forest boundary. SFM will have to play a major role in the remaining forests to ensure that they provide economic revenues from timber, in addition to the many environmental services.

Responses to this article can be read online at:

http://www.ecologyandsociety.org/voll3/iss 1/art25/responses/

\section{Acknowledgments:}

We thank the following people who generously provided literature and comments for this review: Grahame Applegate, Joe Walston, Michael Poulsen, Will Duckworth, Don Gilmour, Patrick Durst, Simmathri Appanah, Gary Paoli, and Neil Franklin. We thank two anonymous reviewers for their comments and edits. The work by Erik Meijaard is made possible by the generous support of the American people through the United States Agency for International Development.

\section{LITERATURE CITED}

Aguilar, F. X., and R. P. Vlosky. 2007. Consumer willingness to pay price premiums for environmentally certified wood products in the U.S. Forest Policy and Economics 9(8):1100-1112.

Asia-Pacific Forestry Commission. 2006. Taking stock: assessing progress in developing and implementing codes of practice for forest harvesting in ASEAN member countries. Food and Agriculture Organization and Association of Southeast Asian Nations, Jakarta, Indonesia. Available online at: http://www.fao.org/docrep/010/ag113e/AG113E00. HTM.

Bennett, E. L. 2004. Seeing the wildlife and the trees: improving timber certification to conserve tropical forest wildlife. Wildlife Conservation 
Society and The World Bank, New York, New York, USA.

Directorate of Forestry and Wildlife. 2002. The Cambodian forestry code of practice. Biodiversity conservation guidelines for the managed forest. Draft for discussion purposes. Directorate of Forestry and Wildlife, Royal Government of Cambodia, Phnom Penh, Cambodia.

Durst, P., C. Brown, and T. Enters. 2003. Development and implementation of national codes of practice for forest harvesting in Asia and the Pacific. Pages 23-33 in International expert meeting on the development and implementation of national codes of practice for forest harvesting: issues and options, 17-20 November 2003, Kisarazu City, Chiba Prefecture, Japan. Food and Agriculture Organization, Tokyo, Japan.

Fimbel, R. A., A. Grajal, and J. G. Robinson. 2001. The cutting edge: conserving wildlife in logged tropical forests. Columbia University Press, New York, New York, USA.

Food and Agriculture Organization. 1999. Code of practice for forest harvesting in Asia-Pacific. Food and Agriculture Organization, Bangkok, Thailand. Available online at: http://www.fao.org/d ocrep/004/AC142E/AC142E00.HTM.

Food and Agriculture Organization. 2005. State of the world's forests: 2005. Food and Agriculture Organization, Rome, Italy. Available online at: $\underline{\mathrm{htt}}$ p://www.fao.org/docrep/007/y5574e/y5574e00.htm

Food and Agriculture Organization. 2006. Global forest resources assessment 2005. Progress towards sustainable forest management. FAO Forest Paper 147. Food and Agricultural Organization, Rome, Italy. Available online at: http://www.fao.org/forestry/ site/fra2005/en/.

Fredericksen, T. S., and F. E. Putz. 2003. Silvicultural intensification for tropical forest conservation. Biodiversity and Conservation 12 (7):1445-1453.

Gustafsson, L., R. Nasi , R. Dennis, N. H. Nghia, D. Sheil, E. Meijaard, D. P. Dykstra, H. Priyadi, and P. Q. Thu. 2007. Logging for the ark: improving the conservation value of production forests in South East Asia. CIFOR Occasional Paper 48, Center for
International Forestry Research, Bogor, Indonesia. Available online at: http://www.cifor.cgiar.org/Pub lications/Detail?pid=2301.

International Tropical Timber Organization. 1993. ITTO guidelines on the conservation of biological diversity in tropical production forests: a supplement to ITTO guidelines for the sustainable management of natural tropical forests. International Tropical Timber Organization, Yokohama, Japan. Available online at: http://www.itto.or.jp/live/Live Server/149/ps05e.doc.

Jakarta Post. 2007. Group rallies for conservation. Jakarta Post 23 April 2007: 5. Available online at: http://www.thejakartapost.com/news/2007/04/23/grouprallies-conservation.html.

Jennings, S. 2004. HCVF for conservation practitioners. ProForest, Oxford, UK.

Jennings, S., R. Nussbaum, N. Judd, and T. Evans. 2003. The high conservation value forest toolkit. First edition. ProForest, Oxford, UK.

Judd, N., R. Nussbaum, S. Jennings, and T. Evans. 2003a. HCVF toolkit part 1: introduction to $H C V F$. ProForest, Oxford, UK.

Judd, N., R. Nussbaum, S. Jennings, and T. Evans. 2003b. HCVF toolkit part 2: defining high conservation values at a national level - a practical guide. ProForest, Oxford, UK.

Judd, N., R. Nussbaum, S. Jennings, and T. Evans. 2003c. HCVF toolkit part 3: identifying and managing high conservation values forests-a guide for forest managers. ProForest, Oxford, UK.

Klassen, A. 2006. Management considerations for successful implementation of reduced impact logging. Tropical Forest Foundation, Jakarta, Indonesia. Available online at: www.tff-indonesia. org/manuals/5th Manual ENG.pdf.

Kollert, W., and P. Lagan. 2007. Do certified tropical logs fetch a market premium? A comparative price analysis from Sabah, Malaysia. Forest Policy and Economics 9(7):862-868.

Malaysian Timber Certification Council. 2004. Malaysian criteria and indicators for forest management certification [MC\&I(2002)]. Malaysian Timber Certification Council, Kuala Lumpur, 
Malaysia. Available online at: http://www.mtcc.com. my/documents.asp).

Meijaard, E. 2007. When enemies become allies, forests and inhabitants benefit. Jakarta Post Thursday 22 February 2007: 7. Available online at: http://www.thejakartapost.com/news/2007/02/22/whenenemies-become-allies-forests-and-inhabitants-benefit. html.

Meijaard, E., and D. Sheil. 2007a. A logged forest in Borneo is better than none at all. Nature 446:974.

Meijaard, E., and D. Sheil. 2007b. The persistence and conservation of Borneo's mammals in lowland rain forests managed for timber: observations, overviews and opportunities. Ecological Research 23(1):21-34.

Meijaard, E., D. Sheil, R. Nasi, D. Augeri, B. Rosenbaum, D. Iskandar, T. Setyawati, M. Lammertink, I. Rachmatika, A. Wong, T. Soehartono, S.Stanley, and T. O'Brien. 2005. Life after logging: reconciling wildlife conservation and production forestry in Indonesian Borneo. Center for International Forestry Research, Bogor, Indonesia. Available online at: http://www.cifor.cg iar.org/publications/pdf files/books/BMeijaard0501E0. pdf.

Meijaard, E., D. Sheil, R. Nasi, and S. A. Stanley. 2006. Wildlife conservation in Bornean timber concessions. Ecology and Society 11(1): 47. [online] URL: http://www.ecologyandsociety.org/voll1/ iss $1 / \operatorname{art} 47 /$.

Ministry of Forestry and Estate Crops. 2000. Principles and practices for forest harvesting in Indonesia. Ministry of Forestry and Estate Crops, Jakarta, Indonesia.

Nussbaum, R., and M. Simula. 2004. The forest certification handbook. Earthscan, London, UK.

Poulsen, M. K., B. Phanthavong, C. N. Sisomphane, and B. Phutaamath. 2005. Biodiversity surveys of production forest areas. SUFORD Technical Report. Sustainable Forestry and Rural Development Project, Vientiane, Laos.

Poulsen, M. K., B. Phanthavong, C. N. Sisomphane, and B. Phutaamath. 2006. Review of biodiversity in production forest areas in support of HCVF identification. Sustainable Forestry and
Rural Development Project, Vientiane, Laos.

ProForest/Rainforest Alliance. 2003. Identifying, managing and monitoring high conservation value forests in Indonesia: a toolkit for forest managers and other stakeholders. Version 1. Rainforest Alliance, New York, New York, USA, and ProForest, Oxford, UK.

Sist, P., and N. Brown. 2004. Silvicultural intensification for tropical forest conservation: a response to Fredericksen and Putz. Biodiversity and Conservation 13(12):2381-2385.

Sist, P., D. Dykstra, and R. Fimbel. 1998. Reduced-impact logging guidelines for lowland and hill dipterocarp forests in Indonesia. CIFOR Occasional Paper 15, Center for International Forestry Research, Bogor, Indonesia. Available online at: http://www.cifor.cgiar.org/Publications/Detail? pid=360.

Stibig, H.-J., R. Upik, R. Beuchle, Hildanus, S. Mubareka. 2003. The land cover map for South East Asia in the year 2000. GLC2000 database. European Commision Joint Research Centre, Ispra, Italy. [online] URL: http://www-gem.jrc.it/glc2000

Sustainable Forestry and Rural Development Project. 2006. Review of ProForest HCVF methodology and its application in Lao PDR with the view of further simplification. Sustainable Forestry and Rural Development Project, Vientiane, Laos.

World Conservation Union. 2006. Guidelines for the conservation and sustainable use of biodiversity in tropical timber production forests. IUCN World Conservation Union, Gland, Switzerland. Available online at: www.iucn.org/themes/fcp/publications/files/ itto-biodiversity-guidelines-june2006.pdf. 
Appendix 1. Overview of High Conservation Value Forest (HCVF) assessments conducted at the Forest Management Unit level in Southeast Asia. Note: Data for APRIL were supplied by the company 
Appendix 2. An overview of regional sustainable forest management fora in South-East Asia

$$
\text { Please click here to download file 'appendix2.pdf'. }
$$

